\title{
Oncolytic activity of reovirus in HPV positive and negative head and neck squamous cell carcinoma
}

Timothy Cooper ${ }^{1}$, Vincent L Biron ${ }^{1}$, David Fast ${ }^{2}$, Raymond Tam ${ }^{3}$, Thomas Carey ${ }^{4}$, Maya Shmulevitz ${ }^{5^{*}}$ and Hadi Seikaly ${ }^{1 *}$

\begin{abstract}
Background: The management of patients with advanced stages of head and neck cancer requires a multidisciplinary and multimodality treatment approach which includes a combination of surgery, radiation, and chemotherapy. These toxic treatment protocols have significantly improved survival outcomes in a distinct population of human papillomavirus (HPV) associated oropharyngeal cancer. HPV negative head and neck squamous cell carcinoma (HNSCC) remains a challenge to treat because there is only a modest improvement in survival with the present treatment regimens, requiring innovative and new treatment approaches. Oncolytic viruses used as low toxicity adjunct cancer therapies are novel, potentially effective treatments for HNSCC. One such oncolytic virus is Respiratory Orphan Enteric virus or reovirus. Susceptibility of HNSCC cells towards reovirus infection and reovirus-induced cell death has been previously demonstrated but has not been compared in HPV positive and negative HNSCC cell lines.
\end{abstract}

Objectives: To compare the infectivity and oncolytic activity of reovirus in HPV positive and negative HNSCC cell lines.

Methods: Seven HNSCC cell lines were infected with serial dilutions of reovirus. Two cell lines (UM-SCC-47 and UM-SCC-104) were positive for type $16 \mathrm{HPV}$. Infectivity was measured using a cell-based ELISA assay $18 \mathrm{~h}$ after infection. Oncolytic activity was determined using an alamar blue viability assay $96 \mathrm{~h}$ after infection. Non-linear regression models were used to calculate the amounts of virus required to infect and to cause cell death in $50 \%$ of a given cell line $\left(E C_{50}\right)$. $E C_{50}$ values were compared.

Results: HPV negative cells were more susceptible to viral infection and oncolysis compared to HPV positive cell lines. $\mathrm{EC}_{50}$ for infectivity at $18 \mathrm{~h}$ ranged from multiplicity of infection (MOI) values (PFU/cell) of 18.6 (SCC-9) to 3133 (UM-SCC 104). EC 50 for cell death at $96 \mathrm{~h}$ ranged from a MOI (PFU/cell) of $1.02 \times 10^{2}$ (UM-SCC-14A) to $3.19 \times 10^{8}$ (UM-SCC-47). There was a $3 \times 10^{6}$ fold difference between the least susceptible cell line (UM-SCC-47) and the most susceptible line (UM-SCC 14A) EC 50 for cell death at $96 \mathrm{~h}$.

Conclusions: HPV negative HNSCC cell lines appear to demonstrate greater reovirus infectivity and virus-mediated oncolysis compared to HPV positive HNSCC. Reovirus shows promise as a novel therapy in HNSCC, and may be of particular benefit in HPV negative patients.

Keywords: Reovirus, Head and neck cancer, Squamous cell carcinoma, HPV

\footnotetext{
*Correspondence: shmulevi@ualberta.ca; hadi.seikaly@albertahealthservices.ca

${ }^{5}$ Department of Medical Microbiology and Immunology, University of

Alberta, 6-142 J Katz Group Centre for Pharmacy \& Health Research,

Edmonton, AB T6G 2E1, Canada

${ }^{1}$ Division of Otolaryngology - Head and Neck Surgery, Department of

Surgery, University of Alberta, 1E4 University of Alberta Hospital, 1E4 Walter

Mackenzie Center, 8440112 St., Edmonton, AB T6G 2B7, Canada

Full list of author information is available at the end of the article
} 


\section{Background}

Head and neck squamous cell carcinoma (HNSCC) is a devastating disease that affects all aspects of the patient's life, even in survivorship [1]. The management of patients with advanced stages of this disease requires a multidisciplinary and multimodality treatment approach which includes a combination of surgery, radiation, and chemotherapy. These toxic treatment protocols have significantly improved survival outcomes, especially in a distinct population of human papillomavirus (HPV) associated oropharyngeal cancer [2-7]. HPV is an important risk factor for a subset of HNSCC [8-10] and types 16 and 18 are particularly high risk for oncogenic transformation [11]. Patients with HPV associated head and neck cancer tend to be younger and less likely to have a significant history of smoking and alcohol consumption in comparison to those affected by non-HPV related head and neck cancer $[8,12]$. Advanced stage HPV negative HNSCC remains a challenge to treat because there is only a modest improvement in survival outcomes despite advances in therapy and the increasing toxicity of the different protocols [2,4-6]. This subset of patients, therefore, requires innovative and new treatment approaches.

The use of oncolytic viruses as a low toxicity adjunct cancer therapy is a novel and potentially effective treatment for HNSCC. One such oncolytic virus is Respiratory Orphan Enteric virus or reovirus [13-18]. Reovirus, from the family Reoviridae, is a non-enveloped, double stranded RNA virus that infects the upper respiratory and gastrointestinal tracts of humans with minimal symptoms [19]. Reovirus shows potent anti-tumor activity in a variety of tumor models, including models of HNSCC [20-27]. Multiple mechanisms mediate the strong specificity of reovirus towards cancer cells and especially towards cells with activated Ras signalling [16,28-33]. A proprietary formulation of the type 3 Dearing reovirus strain, called Reolysin ${ }^{\oplus}$, is undergoing numerous phase I and phase II clinical trials and is currently in a phase III trial $[19,34,35]$.

Susceptibility of HNSCC cells towards reovirus infection and reovirus-induced cell death has been previously demonstrated in both in vitro and mouse models $[22,26,36,37]$, but the effectiveness and infectivity of reovirus in HPV positive and negative head and neck cancer cell lines has not been examined. The objectives of this study were to compare the infectivity and oncolysis of reovirus in HPV positive and negative HNSCC cell lines.

\section{Methods}

\section{Cell lines}

SCC-9, SCC-25, FaDU and L929 were purchased from ATC and maintained according to instructions. UMSCC-14A, UM-SCC-38, UM-SCC-47, and UM-SCC-104 were obtained from Dr. Thomas Carey at the University of Michigan and maintained according to instructions. UMSCC-47 and UM-SCC-104 are both positive for high risk HPV 16 and express viral proteins E6 and E7 [38-40].

\section{Virus}

Reovirus serotype 3 Dearing was propagated in L929 cells and purified by ultracentrifugation on cesium chloride $(\mathrm{CsCl})$ gradients as previously described [41]. Virusinfected cells were freeze-thawed and twice extracted with Vertrel XF (Dymar Chemicals) as previously described [41] and then layered onto $1.25-$ to $1.45-\mathrm{g} / \mathrm{ml} \mathrm{CsCl}$ gradients. Virus was banded at 23,000 rpm for $5 \mathrm{~h}$ and dialyzed extensively against virus dilution buffer $(150 \mathrm{mM} \mathrm{NaCl}$,

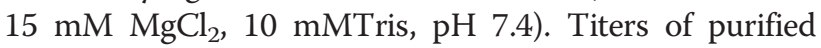
reovirus preparations were obtained using standard plaque titration on L929 cells, and expressed as plaque forming units (PFU) per millilitre [32].

\section{Seeding and infection of cells}

Cells were counted using a TC20 automated cell counter (BioRad). $125 \mu \mathrm{L}$ of cells at a concentration of $2.5 \times 10^{5}$ cells/ $\mathrm{mL}$ were seeded into each well of a 96 well plate to achieve $100 \%$ confluence at time of infection. Serial dilutions of reovirus serotype 3 Dearing ranging from $4.8 \times 10^{8}$ to $1.43 \times 10^{1} \mathrm{PFU} / \mathrm{mL}$ (relative to L929 cells) were prepared in minimal essential media (MEM). Cells were incubated with $50 \mu \mathrm{l}$ of virus at $37^{\circ} \mathrm{C}$ for 1 hour, then returned to virus-free complete medium for the remaining incubation period under standard tissue culture conditions.

\section{Cell-based ELISA assay for infectivity}

Eighteen hours after infection, cells were washed with PBS, fixed with methanol, and stored in blocking solution (Bovine serum albumin, PBS, Triton X-100). Cells were incubated with rabbit anti-reovirus primary antibody (1:5000, blocking solution), washed with PBS-T (PBS, Triton X-100) solution, then incubated with goat anti-rabbit alkaline phosphatase antibody (1:4000, blocking solution). Following extensive washes with PBS-T, $200 \mu \mathrm{L}$ of P-nitrophenyl phosphate in diethanolamine buffer $(1 \mathrm{mg} / \mathrm{mL})$ was added to each well. Plates were incubated at room temperature for 80 minutes, and absorbance was measured at $405 \mathrm{~nm}$ using a spectrophotometer (EnVision Multilabel Reader, Perkin Elmer).

\section{Alamar blue viability assay}

Alamar blue is a commonly used indicator in cell viability assays [42]. At 96 hours after infection, $20 \mu \mathrm{L}$ of $440 \mu \mathrm{M}$ alamar blue in sterile PBS diluted 1:10 with $\mathrm{ddH}_{2} \mathrm{O}$ was added to each well of a 96-well plate. Following incubation for 2 hours at $37^{\circ} \mathrm{C}$, fluorescence was measured at excitation/ emission wavelengths of 544/590 nm respectively (Fluostar OPTIMA plate reader, BMG Labtech). 


\section{Calculation of 96 hour viability}

Using the measured fluorescence from the alamar blue assay, viability at $96 \mathrm{~h}$ was calculated in the well infected with reovirus at a concentration of $2.40 \times 10^{8} \mathrm{PFU} / \mathrm{mL}$. Fluorescence was averaged from two or more duplicates within each experiment. Viability was expressed as a percentage with $100 \%$ viability determined by the fluorescence of the uninfected cells and $0 \%$ viability calculated as an average of the fluorescence of wells containing media but not seeded with cells. Mean viability was calculated for each cell line from three or more independent experiments. Statistically significant outliers and experiments with technical issues related to uneven seeding of cells were excluded from analysis.

\section{Calculation of $\mathrm{EC}_{50}$ values}

Effective concentration 50 or $\mathrm{EC}_{50}$ is a term used in pharmacodynamics indicating the concentration required to have a $50 \%$ maximal effect. In the context of infection with a virus, we have defined $\mathrm{EC}_{50}$ to indicate the amount of virus needed to infect $50 \%$ of cells at 18 hours postinfection, as measured by a cell-based ELISA assay. To quantify reovirus-induced cell death, we have defined $\mathrm{EC}_{50}$ to indicate the amount of virus required to reduce cell viability to $50 \%$ (relative to untreated cells) at 96 hours postinfection, as measured by an alamar blue viability assay. Absorbance (infectivity) or fluorescence (cell viability) values were plotted against multiplicity of infection (MOI, PFU/cell). Baseline and maximum response were established from uninfected cells (maximum viability, minimum infectivity), media alone (minimum viability), or maximally-infected L929 cells (maximum infectivity). Mean absorbance or fluorescence at a given viral concentration was calculated as the mean of two or more duplicates within the same experiment. Three or more independent experiments were used to generate a dose-response curve for each cell line (Prism; Graph-Pad Software Inc., San Diego, CA). From this, $\mathrm{EC}_{50}$ values were calculated by fitting a standard equation for a sigmoidal dose-response curve.

\section{Statistical analysis}

Student's $t$-test was used to compare $\mathrm{EC}_{50}$ values for infectivity and oncolysis between cell lines. Student's $t$-test was also used to compare cell viability at $96 \mathrm{~h}$. $\mathrm{P}<0.05$ was accepted as statistically significant.

\section{Ethics}

Institutional ethics review board approval was obtained from the University of Alberta Health Research Ethics Board prior to the commencement of the study.

\section{Results}

Infectivity

$\mathrm{EC}_{50} \mathrm{MOI}$ for infectivity at $18 \mathrm{~h}$ indicates the number of reovirus particles per cell that were sufficient to achieve infection and active replication in $50 \%$ of cells at this time point. The HNSCC cell lines demonstrated variable susceptibility to infection by reovirus at $18 \mathrm{~h}$. The cell lines listed from most to least susceptible to reovirus infection at $18 \mathrm{~h}$ and their corresponding $\mathrm{EC}_{50} \mathrm{MOI}$ values (PFU/cell) were SCC-9 (18.6 \pm 0.7$)$, FaDU (28.4 \pm 0.7$)$, SCC-25 (51.2 \pm 1.6$)$, UM-SCC-14A (77.3 \pm 3.1$)$, UMSCC-38 $(651 \pm 11)$, UM-SCC-47 $(1425 \pm 23)$, and UMSCC-104 (3133 \pm 86$)$ (Figure 1). The most susceptible HNSCC cell lines were SCC-9 and FaDU. These cell lines required a mean of 18.6 and 28.4 virus particles per cell to achieve $50 \%$ infectivity at $18 \mathrm{~h}$ respectively. The least susceptible cell lines, UM-SCC-47 and UM-SCC104, were both HPV positive. They required a mean of 1425 and 3133 virus particles per cell to achieve 50\% infection, respectively. In comparing the two HPV positive cell lines individually to each of the $5 \mathrm{HPV}$ negative cell lines, the HPV positive HNSCC cell lines were less susceptible to infection by reovirus with statistical significance $(\mathrm{p}<0.01)$.

\section{$96 \mathrm{~h}$ viability}

Differences in percent viability were also found between cell lines $96 \mathrm{~h}$ after infection with reovirus at a concentration of $2.40 \times 10^{8} \mathrm{PFU} / \mathrm{mL}$. This equates to an MOI of $7.68 \times 10^{3}$ viral particles per cell. The mean percent viabilities for each cell line from least to greatest were UM-SCC$14 \mathrm{~A}(6.7 \pm 5.0 \%), \mathrm{FaDU}(10.9 \pm 3.7 \%)$, SCC-9 (33.2 $\pm 9.9 \%)$,

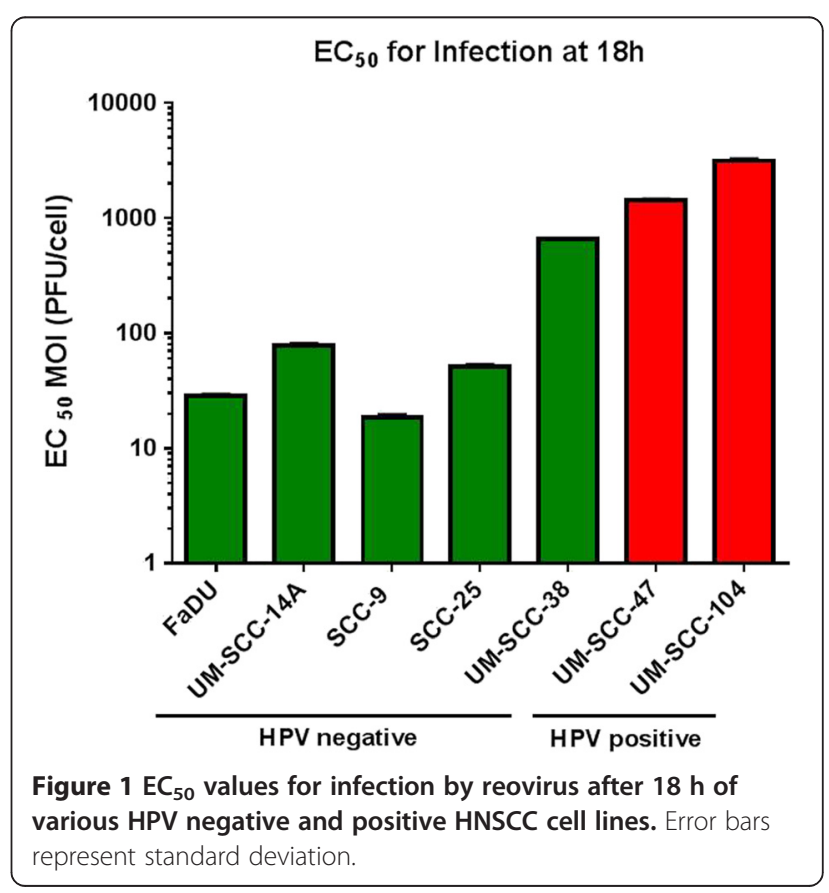


SCC-25 (54.6 $\pm 21.5 \%), \quad$ UM-SCC-104 $(82.3 \pm 6.5 \%)$, UM-SCC-38 $(83.9 \pm 16.3 \%)$, and UM-SCC-47 $(97.2 \pm 4.7 \%)$ (Figure 2). The two most susceptible cell lines to virallyinduced cytotoxicity were UM-SCC-14A and FaDU which were both HPV negative. Of the three cell lines with the greatest viability at this time point, two were HPV positive (UM-SCC-104 and UM-SCC-47). UM-SCC-47 had more viable cells with statistical significance than all of the HPV negative cell lines except for UM-SCC-38 $(p=0.17)$. UMSCC-104 had more viable cells with statistical significance than UM-SCC-14A, FaDU, and SCC-9 (all with p <0.01). The HPV positive cell lines were highly resistant to oncolysis by reovirus and showed only minimal viral-induced cytotoxicity at $96 \mathrm{~h}$, even with high concentrations of reovirus used for infection. Images taken from brightfield microscopy at 96 hours after infection of the UM-SCC-14A, UM-SCC-47, and UM-SCC-104 cell lines demonstrate this difference (Figure 3).

\section{Oncolysis}

The head and neck cancer cell lines had variable $\mathrm{EC}_{50}$ values for cell death at $96 \mathrm{~h}$. The HNSCC cell line most susceptible to reovirus was UM-SCC-14A (HPV negative) with a mean $\mathrm{EC}_{50} \mathrm{MOI}$ (PFU/cell) value of 102 (95\%CI [93-112]). This means that 102 reovirus particles per cell were sufficient to cause $50 \%$ cell death in this cell line. The remaining cell lines from most to least susceptible to reovirus-mediated oncolysis and their corresponding $\mathrm{EC}_{50} \mathrm{MOI}$ (PFU/cell) values were $\mathrm{FaDU}$ (388, CI[378-397]), SCC-9 $\left(4.24 \times 10^{3}\right.$, CI $\left[4.00 \times 10^{3}-\right.$ $\left.\left.4.49 \times 10^{3}\right]\right), \operatorname{SCC}-25\left(1.07 \times 10^{4}, \mathrm{CI}\left[1.03 \times 10^{4}-1.10 \times 10^{4}\right]\right)$,

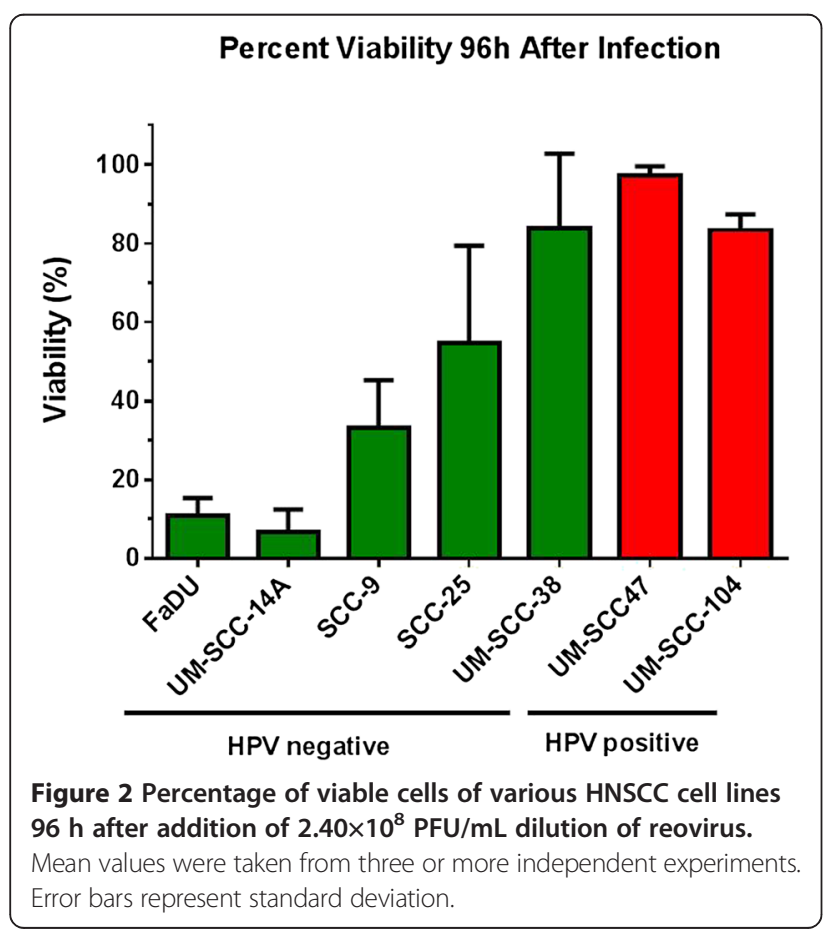

UM-SCC-38 $\left(2.99 \times 10^{4}, \mathrm{CI}\left[2.80 \times 10^{4}-3.18 \times 10^{4}\right]\right)$, UMSCC-104 $\left(4.04 \times 10^{5}, \mathrm{CI}\left[2.62 \times 10^{5}-6.23 \times 10^{5}\right]\right)$, and UMSCC-47 $\left(3.19 \times 10^{8}, \mathrm{CI}\left[1.31 \times 10^{8}-7.76 \times 10^{8}\right)\right.$ (Figure 4$)$. The two HPV positive cell lines were more resistant to reovirus-mediated oncolysis in comparison to the HPV negative cell lines ( $\mathrm{p}<0.01$ in all cases).

\section{Discussion}

The use of viruses in cancer therapy is a rapidly expanding area of research $[13,16,23,27,34]$. However, the use of viral oncolytic therapy has yet to make the transition from bench to bedside in standard practice. Reovirus was first shown to have an oncolytic effect in head and neck cancer cells by Ikeda et al. [22] using in vitro and in vivo models. This effect has been demonstrated in numerous head and neck cell lines $[24,25,36,37]$. The oncolytic effect is believed to be independent of epidermal growth factor receptor (EGFR) activation and molecular predictors of response have yet to be identified [25]. Preclinical studies have shown the effectiveness of a combination of reovirus, paclitaxel and cisplatin in head and neck cancer lines [24]. Also, animal models have suggested a role for reovirus as an adjunct in surgically resected disease with positive margins [37]. Intravenously administered reovirus in combination with carboplatin and paclitaxel has been shown to have activity in advanced stage and recurrent head and neck cancer in a recently published phase I/II clinical trial [35]. An ongoing phase III trial is investigating intravenous reovirus in combination with paclitaxel and carboplatin (Reo 018).

Reovirus has variable infectivity and oncolytic activity in head and neck cancer cell lines and the mechanism behind this variable susceptibility has yet to be elucidated but is likely multifactorial. Our findings suggest an important difference in the susceptibility of head and neck cancer cells to reovirus based on HPV status. The HPV negative cell lines used were much more susceptible than the HPV positive cells to both infection by reovirus and virus-mediated oncolysis. There was a $>150$ fold difference in the amount of virus required to infect $50 \%$ of cells in the most susceptible cell line (SCC-9) and the least susceptible cell line (UM-SCC-104). Similarly, there was a dramatic difference between oncolysis based on HPV status. There was a $3 \times 10^{6}$ fold difference in the $\mathrm{EC}_{50}$ values of the most susceptible cell line UMSCC-14A (HPV negative) and the most resistant cell line UM-SCC-47 (HPV positive). For both infectivity at $18 \mathrm{~h}$ and oncolysis at $96 \mathrm{~h}$, the HPV negative cells were more susceptible than the HPV positive cells by highly significant values. Our study is the first to compare the oncolytic activity of reovirus in HPV positive and negative head and neck cancer cell lines. Also, it is the first to compare reovirus infectivity among head and neck cancer cell lines. 


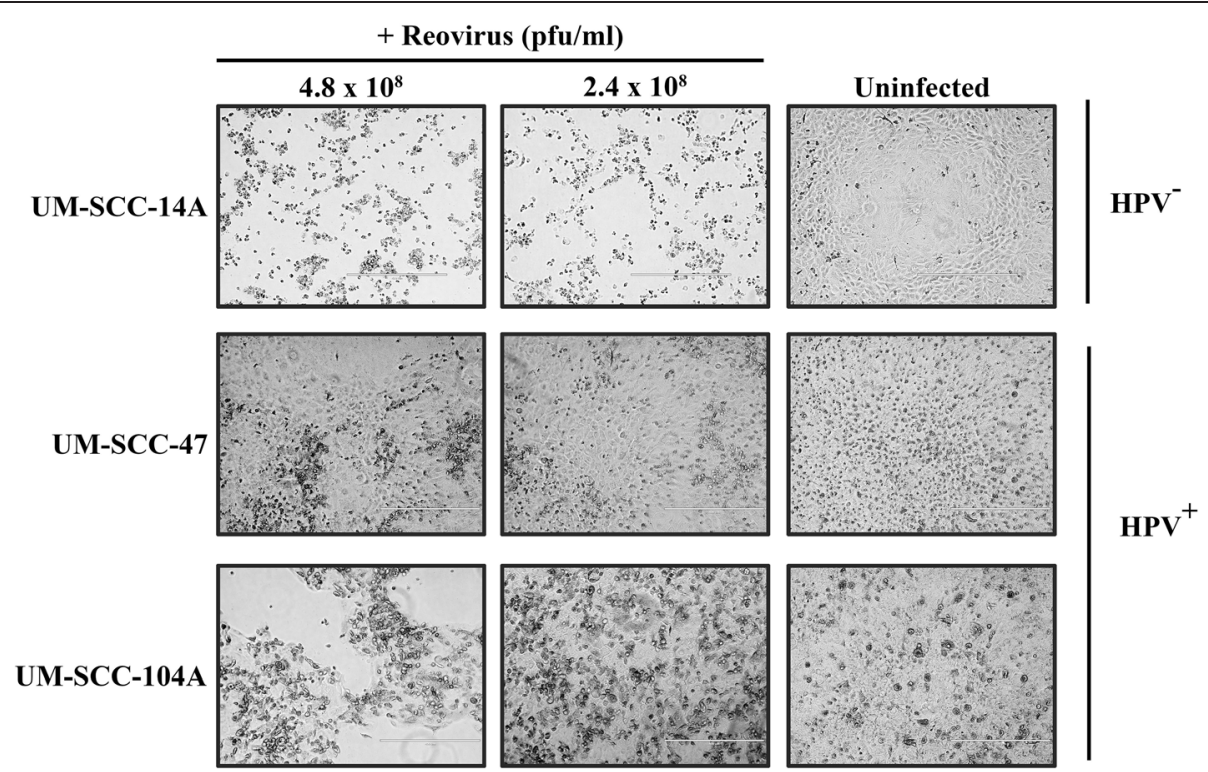

Figure 3 Brightfield microscopy of UM-SCC-14A, UM-SCC-47, and UM-SCC-104 cells $96 \mathrm{~h}$ after the addition of $4.8 \times 10^{8}$ and $2.4 \times 10^{8}$ $\mathrm{PFU} / \mathrm{mL}$ reovirus dilutions according to experiment protocol compared to uninfected controls

HPV positive (vs negative) oropharyngeal squamous cell carcinoma (OPSCC) has been shown to have a more favourable response to treatment with surgical and nonsurgical treatments [6,7]. However, when considering treatment with cetuximab, a monoclonal antibody that targets EGFR, a number of studies suggest HPV positive OPSCC tumors may be less responsive to this chemotherapeutic drug $[43,44]$. This is consistent with several studies showing an inverse relationship with HPV positivity [44]. It is important to note that both reovirus and

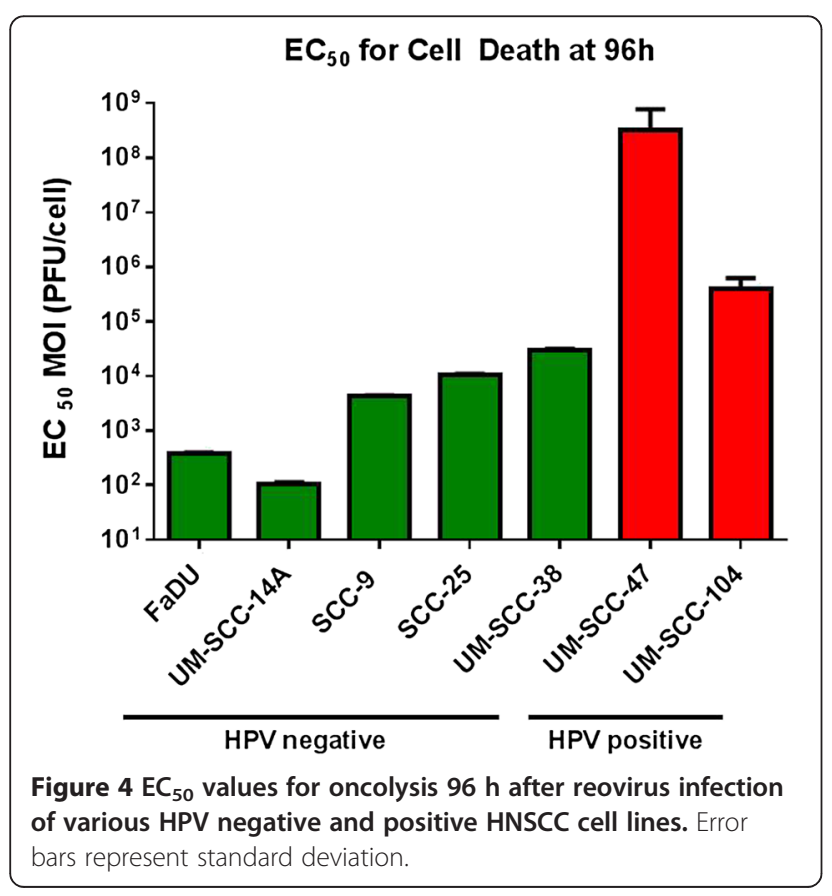

cetuximab act on Ras-dependent pathways [44]. Taken together, our results showing resistance to reovirus in HPV-positive HNSCC cell lines could therefore be due to a lack of EGFR expression and its downstream Rasdependent treatment response.

Novel therapies are needed in head and neck cancer, especially in patients with HPV negative malignancies. Conventional therapy is associated with substantial morbidity and long-term complications [1], and progress has been limited in the use of adjuvant therapy in patients with advanced stage HPV negative cancers [45]. Reovirus shows promise as a potential novel therapy in HPV negative head and neck cancer.

Further research is required to identify additional molecular markers for susceptibility to reovirus to identify patients most likely to benefit from adjunctive reovirus therapy. HPV negative patients, a group with a poor prognosis relative to those with HPV-related head and neck cancer, are identified as a group to target in future reovirus trials. Ongoing and future trials investigating reovirus in head and neck cancer may need to perform subgroup analysis based on HPV status.

Commonly described features of HNSCC cell lines include tumor subsite, staging, and treatment modalities utilized. Although clinically relevant, the smoking history of the patients from which these cell lines have been derived is not well described in the literature. The smoking status of the patients from which FaDU and SCC-9 were derived is not documented. The source of SCC-25 had an extensive history of smoking [46]. Of the cell lines obtained from Dr. Carey and the University of Michigan, UM-SCC-14A, UM-SCC-38, and UM-SCC- 
104 were derived from smokers [47]. However, there is no laboratory documentation regarding the smoking status of the patient from which the HPV positive UMSCC-47 cell line was derived. Despite this limitation in clinical history, numerous papers have delineated genotypic differences between these and other HNSCC cell lines [48].

There are several limitations to this study. The behavior of cell lines in in vitro experiments is variable. Confounding factors between the cell lines used beyond HPV status may have an impact on results. Head and neck cancer is a molecularly and genetically heterogeneous entity $[48,49]$. Therefore, caution must be used in generalizing the effect of reovirus on a selection of cell lines to all HPV positive or negative head and neck cancers. However, this study design allowed for a time and cost efficient way to test a hypothesis regarding the activity of reovirus and HPV positive and negative head and neck cancers. Further investigation into the effect of reovirus on additional HPV positive and negative cell lines as well as in HPV positive and negative animal models is warranted.

\section{Conclusions}

HPV negative cell lines appear to be more susceptible to reovirus infection and oncolysis than their HPV positive counterparts. Reovirus shows promise as a potential novel therapy in HPV negative head and neck cancer.

\section{Ethics approval}

Prior to commencement, health research ethics board approval was obtained from the University of Alberta Health Research Ethics Board.

\begin{abstract}
Abbreviations
CsCl: Cesium chloride; $\mathrm{EC}_{50}$ : Effective concentration 50\%; EGFR: Epidermal growth factor receptor; HNSCC: Head and neck squamous cell carcinoma; HPV: Human papillomavirus; $\mathrm{MgCl}_{2}$ : Magnesium chloride; MOI: Multiplicity of infection; OPSCC: Oropharyngeal squamous cell carcinoma; PBS: Phosphate buffered saline; PFU: Plaque forming units; RPM: Rotations per minute.
\end{abstract}

\section{Competing interests}

The authors declare that they have no competing interests.

\section{Authors' contributions}

TC contributed with conception and design, conduction of experiments, data collection, data analysis, writing and revision of the manuscript. VB contributed with conception and design, data analysis, and writing and revision of the manuscript. DF contributed with conduction of experiments, data collection, and critical revision of the manuscript. RT contributed with conduction of experiments, data collection, and critical revision of the manuscript. TEC contributed with conception and design and critical revision of the manuscript. MS contributed with conception and design, data analysis, and writing of the manuscript. HS contributed with conception and design, data analysis, and writing and revision of the manuscript. All authors have given final approval of the version to be published.

Authors' information

Hadi Seikaly and Maya Shmulevitz are co-senior authors.

\section{Acknowledgements}

We would like to acknowledge Heather Eaton, Adil Mohamed, Wong Kong Yip, Kevin James, Alicia Guenette, and Georgi Trifonov from Dr. Shmulevitz's laboratory for assistance with cell culture and reagents. We would also like to thank Dr. Carey's laboratory from the University of Michigan for collaborative contribution of cell lines and advice on cell line maintenance.

\section{Financial Support/Disclosures}

Funding from the Division of Otolaryngology Head - Neck Surgery, University of Alberta.

\section{Author details}

${ }^{1}$ Division of Otolaryngology - Head and Neck Surgery, Department of Surgery, University of Alberta, 1E4 University of Alberta Hospital, 1E4 Walter Mackenzie Center, 8440112 St., Edmonton, AB T6G 2B7, Canada. 'Faculty of Science 1-001 CCIS, University of Alberta, Edmonton, AB T6G 2E9, Canada. ${ }^{3}$ Faculty of Medicine and Dentistry, University of Alberta, $2 J 2$ WC Mackenzie Health Sciences Centre, Edmonton, AB T6G 2R7, Canada. ${ }^{4}$ Department of Head and Neck Surgery, University of Michigan, 5311B Med Sci I, Ann Arbor, MI 48109-5616, USA. ${ }^{5}$ Department of Medical Microbiology and Immunology, University of Alberta, 6-142 J Katz Group Centre for Pharmacy \& Health Research, Edmonton, AB T6G 2E1, Canada.

Received: 5 August 2014 Accepted: 9 February 2015

Published online: 24 February 2015

\section{References}

1. Rutten H, Pop LA, Janssens GO, Takes RP, Knuijt S, Rooijakkers AF, et al. Long-term outcome and morbidity after treatment with accelerated radiotherapy and weekly cisplatin for locally advanced head-and-neck cancer: Results of a multidisciplinary late morbidity clinic. Int I Radiat Oncol, Biol, Phys. 2011;81(4):923-9.

2. Lau HY, Brar S, Klimowicz AC, Petrillo SK, Hao D, Brockton NT, et al. Prognostic significance of p16 in locally advanced squamous cell carcinoma of the head and neck treated with concurrent cisplatin and radiotherapy. Head Neck. 2011;33(2):251-6.

3. Laco J, Nekvindova J, Novakova V, Celakovsky P, Dolezalova H, Tucek L, et al. Biologic importance and prognostic significance of selected clinicopathological parameters in patients with oral and oropharyngea squamous cell carcinoma, with emphasis on smoking, protein p16(INK4a) expression, and HPV status. Neoplasma. 2012;59(4):398-408.

4. Fakhry C, Westra WH, Li S, Cmelak A, Ridge JA, Pinto H, et al. Improved survival of patients with human papillomavirus-positive head and neck squamous cell carcinoma in a prospective clinical trial. J Natl Cancer Inst. 2008;100(4):261-9.

5. Cooper T, Biron V, Adam B, Klimowicz AC, Puttagunta L, Seikaly H. Prognostic utility of basaloid differentiation in oropharyngeal cancer. J Otolaryngol Head Neck Surg. 2013;42:57. 0216-42-57.

6. Ang KK, Harris J, Wheeler R, Weber R, Rosenthal DI, Nguyen-Tan PF, et al. Human papillomavirus and survival of patients with oropharyngeal cancer. N Engl J Med. 2010;363(1):24-35.

7. Bossi P, Orlandi E, Miceli R, Perrone F, Guzzo M, Mariani L, et al. Treatmentrelated outcome of oropharyngeal cancer patients differentiated by HPV dictated risk profile: A tertiary cancer centre series analysis. Ann Oncol. 2014;25(3):694-9.

8. Cardesa A, Nadal A. Carcinoma of the head and neck in the HPV era. Acta Dermatovenerol Alp Panonica Adriat. 2011;20(3):161-73.

9. El-Mofty SK, Patil S. Human papillomavirus (HPV)-related oropharyngeal nonkeratinizing squamous cell carcinoma: Characterization of a distinct phenotype. Oral Surg Oral Med Oral Pathol Oral Radiol Endod. 2006;101(3):339-45.

10. Gillison ML, Koch WM, Capone RB, Spafford M, Westra WH, Wu L, et al. Evidence for a causal association between human papillomavirus and a subset of head and neck cancers. J Natl Cancer Inst. 2000;92(9):709-20.

11. Nichols AC, Faquin WC, Westra WH, Mroz EA, Begum S, Clark JR, et al. HPV-16 infection predicts treatment outcome in oropharyngeal squamous cell carcinoma. Otolaryngol Head Neck Surg. 2009;140(2):228-34.

12. El-Mofty SK, Lu DW. Prevalence of human papillomavirus type 16 DNA in squamous cell carcinoma of the palatine tonsil, and not the oral cavity, in young patients: a distinct clinicopathologic and molecular disease entity. Am J Surg Pathol. 2003;27(11):1463-70. 
13. Coffey MC, Strong JE, Forsyth PA, Lee PW. Reovirus therapy of tumors with activated ras pathway. Science. 1998;282(5392):1332-4.

14. Duncan MR, Stanish SM, Cox DC. Differential sensitivity of normal and transformed human cells to reovirus infection. J Virol. 1978;28(2):444-9.

15. Hashiro G, Loh PC, Yau JT. The preferential cytotoxicity of reovirus for certain transformed cell lines. Arch Virol. 1977;54(4):307-15.

16. Maitra R, Ghalib MH, Goel S. Reovirus: a targeted therapeutic-progress and potential. Mol Cancer Res. 2012;10(12):1514-25.

17. Strong JE, Lee PW. The v-erbB oncogene confers enhanced cellular susceptibility to reovirus infection. J Virol. 1996;70(1):612-6.

18. Strong JE, Tang D, Lee PW. Evidence that the epidermal growth factor receptor on host cells confers reovirus infection efficiency. Virology. 1993;197(1):405-11.

19. Kyula JN, Roulstone V, Karapanagiotou EM, Melcher AA, Harrington KJ. Oncolytic reovirus type 3 (dearing) as a novel therapy in head and neck cancer. Expert Opin Biol Ther. 2012;12(12):1669-78.

20. Errington F, White $C L$, Twigger $K R$, Rose A, Scott $K$, Steele L, et al. Inflammatory tumour cell killing by oncolytic reovirus for the treatment of melanoma. Gene Ther. 2008;15(18):1257-70.

21. Etoh T, Himeno Y, Matsumoto T, Aramaki M, Kawano K, Nishizono A, et al. Oncolytic viral therapy for human pancreatic cancer cells by reovirus. Clin Cancer Res. 2003;9(3):1218-23.

22. Ikeda Y, Nishimura G, Yanoma S, Kubota A, Furukawa M, Tsukuda M. Reovirus oncolysis in human head and neck squamous carcinoma cells. Auris Nasus Larynx. 2004;31(4):407-12.

23. Norman KL, Coffey MC, Hirasawa K, Demetrick DJ, Nishikawa SG, DiFrancesco LM, et al. Reovirus oncolysis of human breast cancer. Hum Gene Ther. 2002;13(5):641-52.

24. Roulstone V, Twigger K, Zaidi S, Pencavel T, Kyula JN, White C, et al. Synergistic cytotoxicity of oncolytic reovirus in combination with cisplatin-paclitaxel doublet chemotherapy. Gene Ther. 2013;20(5):521-8.

25. Twigger K, Roulstone V, Kyula J, Karapanagiotou EM, Syrigos KN, Morgan R et al. Reovirus exerts potent oncolytic effects in head and neck cancer cell lines that are independent of signalling in the EGFR pathway. BMC Cancer 2012;12:368. 2407-12-368.

26. Twigger K, Vidal L, White CL, De Bono JS, Bhide S, Coffey M, et al. Enhanced in vitro and in vivo cytotoxicity of combined reovirus and radiotherapy. Clin Cancer Res. 2008;14(3):912-23.

27. Shmulevitz M, Marcato P, Lee PW. Unshackling the links between reovirus oncolysis, ras signaling, translational control and cancer. Oncogene. 2005;24(52):7720-8.

28. Marcato P, Shmulevitz M, Pan D, Stoltz D, Lee PW. Ras transformation mediates reovirus oncolysis by enhancing virus uncoating, particle infectivity, and apoptosis-dependent release. Mol Ther. 2007;15(8):1522-30.

29. Pan D, Pan LZ, Hill R, Marcato P, Shmulevitz M, Vassilev LT, et al. Stabilisation of p53 enhances reovirus-induced apoptosis and virus spread through p53-dependent NF-kappaB activation. Br J Cancer. 2011;105(7):1012-22.

30. Shmulevitz M, Lee PW. Exploring host factors that impact reovirus replication, dissemination, and reovirus-induced cell death in cancer versus normal cells in culture. Methods Mol Biol. 2012;797:163-76.

31. Shmulevitz M, Marcato P, Lee PW. Activated ras signaling significantly enhances reovirus replication and spread. Cancer Gene Ther. 2010:17(1):69-70.

32. Shmulevitz M, Pan LZ, Garant K, Pan D, Lee PW. Oncogenic ras promotes reovirus spread by suppressing IFN-beta production through negative regulation of RIG-I signaling. Cancer Res. 2010;70(12):4912-21.

33. Pan D, Marcato P, Ahn DG, Gujar S, Pan LZ, Shmulevitz M, et al. Activation of p53 by chemotherapeutic agents enhances reovirus oncolysis. PLoS One. 2013;8(1):e54006

34. Black AJ, Morris DG. Clinical trials involving the oncolytic virus, reovirus: ready for prime time? Expert Rev Clin Pharmacol. 2012;5(5):517-20

35. Karapanagiotou EM, Roulstone V, Twigger K, Ball M, Tanay M, Nutting C, et al. Phase $1 / /$ trial of carboplatin and paclitaxel chemotherapy in combination with intravenous oncolytic reovirus in patients with advanced malignancies. Clin Cancer Res. 2012;18(7):2080-9.

36. Brookes JT, Seikaly H, Lim T, Wong KK, Harris JR, Moore RB. Reovirus salvage of squamous cell cancer-contaminated wounds. J Otolaryngol. 2005:34(1):32-7.

37. Mechor B, Seikaly H, Wong K, Chau J, Uwiera R, Harris JR. Reovirus salvage of positive resection margin: a novel treatment adjunct. J Otolaryngol. 2006;35(2):97-101.
38. Zhao M, Sano D, Pickering CR, Jasser SA, Henderson YC, Clayman GL, et al. Assembly and initial characterization of a panel of 85 genomically validated cell lines from diverse head and neck tumor sites. Clin Cancer Res. 2011;17(23):7248-64

39. Tang AL, Hauff SJ, Owen JH, Graham MP, Czerwinski MJ, Park JJ, et al. UM-SCC-104: a new human papillomavirus-16-positive cancer stem cell-containing head and neck squamous cell carcinoma cell line. Head Neck. 2012;34(10):1480-91.

40. Brenner JC, Graham MP, Kumar B, Saunders LM, Kupfer R, Lyons RH, et al. Genotyping of 73 UM-SCC head and neck squamous cell carcinoma cell lines. Head Neck. 2010;32(4):417-26.

41. Mendez II, Hermann LL, Hazelton PR, Coombs KM. A comparative analysis of freon substitutes in the purification of reovirus and calicivirus. J Virol Methods. 2000;90(1):59-67.

42. Rampersad SN. Multiple applications of alamar blue as an indicator of metabolic function and cellular health in cell viability bioassays. Sensors (Basel). 2012;12(9):12347-60.

43. Koutcher L, Sherman E, Fury M, Wolden S, Zhang Z, Mo Q, et al. Concurrent cisplatin and radiation versus cetuximab and radiation for locally advanced head-and-neck cancer. Int J Radiat Oncol, Biol, Phys. 2011;81(4):915-22.

44. Mirghani H, Amen F, Moreau F, Guigay J, Hartl DM, Lacau St Guily J. Oropharyngeal cancers: Relationship between epidermal growth factor receptor alterations and human papillomavirus status. Eur J Cancer. 2014:50(6):1100-11.

45. Burtness B, Bauman JE, Galloway T. Novel targets in HPV-negative head and neck cancer: overcoming resistance to EGFR inhibition. Lancet Oncol. 2013;14(8):e302-9.

46. Somers KD, Merrick MA, Lopez ME, Incognito LS, Schechter GL, Casey G. Frequent p53 mutations in head and neck cancer. Cancer Res. 1992:52(21):5997-6000.

47. Tang AL, Hauff SJ, Owen JH. UM-SCC-104: a new human papillomavirus-16positive cancer stem cell-containing head and neck squamous cell carcinoman cell line. Head Neck. 2012;34(10):1480-91.

48. Biron VL, Mohamed A, Hendzel MJ, Alan Underhill D, Seikaly H. Epigenetic differences between human papillomavirus-positive and -negative oropharyngeal squamous cell carcinomas. J Otolaryngol Head Neck Surg. 2012;41 Suppl 1:S65-70.

49. Barber BR, Biron VL, Klimowicz AC, Puttagunta L, Cote DW, Seikaly H. Molecular predictors of locoregional and distant metastases in oropharyngeal squamous cell carcinoma. J Otolaryngol Head Neck Surg. 2013;42:53. 0216-42-53.

\section{Submit your next manuscript to BioMed Central and take full advantage of:}

- Convenient online submission

- Thorough peer review

- No space constraints or color figure charges

- Immediate publication on acceptance

- Inclusion in PubMed, CAS, Scopus and Google Scholar

- Research which is freely available for redistribution 